\title{
Rapid Assessment Terhadap Kerusakan Bangunan Akibat Erupsi Merapi Tahun 2010
}

\author{
Any J., ${ }^{1,2}$ Widodo B., ${ }^{1}$ Ribut L., ${ }^{2}$ Hamidin, ${ }^{2}$ dan Evi O. ${ }^{2}$ \\ ${ }^{1}$ Jurusan Teknik Lingkungan FTSP UII; ${ }^{2}$ Pusat Studi Lingkungan (PSL) UII \\ email: widodo.bronto@gmail.com
}

\begin{abstract}
Abstrak
Erupsi Gunungapi Merapi di tahun 2010 memberikan dampak salah satunya adalah kerusakan bangunan. Penelitian ini bertujuan untuk memetakan dan menginventarisasi kerugian bangunan serta memberikan rekomendasi kebijakan rehabilitasi dan rekonstruksi tempat tinggal dan fasilitas permukiman, khususnya di wilayah Kabupaten Sleman. Metode penelitian yang digunakan adalah analisis penginderaan jauh dan sistem informasi geografis serta survey lapangan. Data dasar menggunakan Citra IKONOS, Citra ASTER dan Citra Geo eye-1. Hasil penelitian menunjukkan 3245 buah bangunan mengalami kerusakan berat hingga hancur, semuanya di Kecamatan Cangkringan. Wilayah ini direkomendasikan PVMBG menjadi Kawasan Rawan Bencana III Merapi. Penelitian merekomendasikan Pemerintah Daerah Kabupaten Sleman untuk melakukan relokasi warga dengan pendekatan persuasif dan sistematis berbasis sosial budaya, dengan sistem bedol dusun/kampung, penyediaan wilayah tujuan relokasi yang sesuai dengan wilayah asal, sistem tukar lahan, dan penyediaan fasilitas yang memadai. Rehabilitasi dan rekonstruksi juga perlu memperhatikan penyediaan fasilitas lingkungan permukiman antara lain fasilitas air bersih, fasilitas air limbah dan MCK, fasilitas pengelolaan sampah, fasilitas ruang publik, serta fasilitas jalan dan drainase.
\end{abstract}

Kata kunci: Erupsi Gunungapi Merapi, Kerusakan Bangunan, Rehabilitasi dan rekonstruksi, Kabupaten Sleman

\section{Pendahuluan}

Erupsi Gunungapi Merapi di akhir tahun 2010 disebut yang terbesar selama 100 tahun terakhir. BNPB (2010) melaporkan per 1 Desember 2010 erupsi tanggal 26 Oktober dan 5 November 2010 telah menimbulkan korban 196 orang meninggal akibat luka bakar awan panas, 151 meninggal akibat non luka bakar, 258 luka-luka, serta 410.338 orang harus mengungsi. Kerugian lain akibat erupsi Gunungapi Merapi adalah matinya ternak, rusaknya lahan, matinya tanaman, serta kerusakan bangunan. Salah satu kerugian besar bagi korban adalah luluh lantaknya rumah akibat terjangan awan panas. Rumah merupakan kebutuhan pokok manusia.

Wilayah sekitar Gunungapi Merapi umumnya merupakan wilayah yang subur untuk pertanian. Penelitian Lupiyanto (2005) menyebutkan bahwa daya dukung lahan pertanian di Kawasan Rawan Bencana III Gunungapi merapi sangatlah tinggi. Wajar apabila daerah yang paling rawan ini padat penduduk dan bahkan pusat-pusat kegiatan berada pada lahan ini. Semakin berkembang aktivitas berbagai bentuk kegiatan manusia pada lereng selatan Gunungapi Merapi seperti: pertambangan, pertanian, perkebunan, permukiman, pariwisata, olahraga, dan tempat peristirahatan yang akhirakhir ini menunjukkan peningkatan yang cukup pesat. Apabila sewaktu-waktu aktivitas Gunungapi 
Merapi meningkat, maka daerah tersebut menjadi daerah yang memiliki potensi bahaya dan potensi risiko vulkanik yang ditimbulkan oleh aktivitas Gunungapi Merapi. Salah satu kerugian besar bagi korban adalah luluh lantaknya rumah akibat terjangan awan panas.

Hingga kini belum diketahui pasti berapa kerugian yang diderita penduduk dari segi bangunan atau rumah yang dimiliki, baik rusak total, sedang, hingga ringan. Belum diketahui pasti juga sebaran spasial kerugian tersebut. Upaya mendesak perlu segera dilakukan untuk memetakan dan menginventarisasi kerugian bangunan, sehingga dapat diputuskan kebijakan rehabilitasi dan rekonstruksi tempat tinggal dan fasilitas permukimannya. Penelitian ini dilakukan untuk menjawab hal tersebut dengan judul "Kajian Kerusakan Bangunan Akibat Erupsi Gunungapi Merapi Tahun 2010 di Kabupaten Sleman”.

\section{Metode Penelitian}

Pengumpulan data dilakukan dengan cara observasi, pengukuran lapangan, dan interpretasi dari data lain. Data utama yang diambil adalah data luncuran awan panas dan data bangunan yang terdampak dari awan panas tersebut. Data sekunder diambil dari Kecamatan Dalam Angka, BPS, khususnya untuk data sarana dan prasarana wilayah terutama yang terdampak awan panas. Oleh karena itu pengambilan sampel mempertimbangkan lokasi luncuran awan panas dan distribusi bangunan/sarana prasarana wilayah.

Analisis pertama yang dilakukan adalah analisis penginderaan jauh. Analisis ini digunakan untuk membuat peta kondisi bangunan sebelum erupsi Gunungapi Merapi tahun 2010 serta kondisi pasca erupsi. Analisis kondisi sebelum erupsi dengan teknik interpretasi citra IKONOS. Analisis pascaerupsi dengan interpretasi Citra ASTER dan Citra Geo eye-1 mengingat ketersediaan dan keterjangkauan penyediaan citra.

Tahap-tahap dalam analisis data penginderaan jauh dipilah menjadi 3, yaitu: deteksi, identifikasi dan pengenalan akhir. Tahap lanjutan dan tahapan awal adalah menganalisis arti penting objek tersebut dan mensintesis atau menggabungkan hasil analisis citra untuk tujuan tertentu (Sutanto, 1995). Analisis citra satelit yang dilakukan sebanyak 3 (tiga) kali dengan jenis citra yang berbeda. Citra-citra yang diinterpretasi antara lain Citra ASTER, Citra Geo eye-1 dan Citra Ikonos. Keseluruhan interpretasi citra menggunakan metode digitizing on screen. Perbedaan jenis citra disesuaikan dengan tujuan interpretasi.

Analisis kedua adalah analisis SIG yang digunakan untuk memperoleh data jumlah bangunan yang rusak karena luncuran awan panas. Ekspresi tumpang susun data menggunakan ekspresi logis 
dengan logika boolean (if...then...else). Hasil akhir dari analisis ini adalah data kerusakan bangunan akibat awan panas. Analisis GIS dalam penelitian ini menggunakan perangkat lunak Arcview GIS dan Globalmapper. Arcview GIS digunakan untuk menganalisis data berbentuk vektor seperti data bangunan, daa sarana dan prasarana serta data jalur awan panas dari hasil interpretasi citra. Data vektor ini disusun dan dilengkapi dengan database sehingga menjadi basis data terintegrasi antara gambar/peta dengan tabel. Analisis 3 Dimensi menggunakan perangkat lunak Globalmapper. Hal ini dilakukan karena GlobalMapper sangat ringan dalam memproses data 3 dimensi yang rumit sekalipun. Data 3 dimensi yang dioleh diambil dari data DEM dari Citra ASTER dengan resolusi 30 m. Data tersebut diolah dan ditumpangsusunkan dengan data vektor untuk memperkuat analisis.

Analisis ketiga adalah analisis kerusakan bangunan. Berdasarkan hasil analisis penginderaan jauh dan survei, maka dilakukan estimasi dan perhitungan kerusakan bangunan akibat erupsi Gunungapi Merapi. Analisis juga mengidentifikasi tingkat kerusakan bangunan dengan keluaran berupa peta tingkat kerusakan. Analisis ini secara umum dilakukan dengan spasial dan deskriptif. Berikut adalah diagram alir tahapan pelaksanaan penelitian.

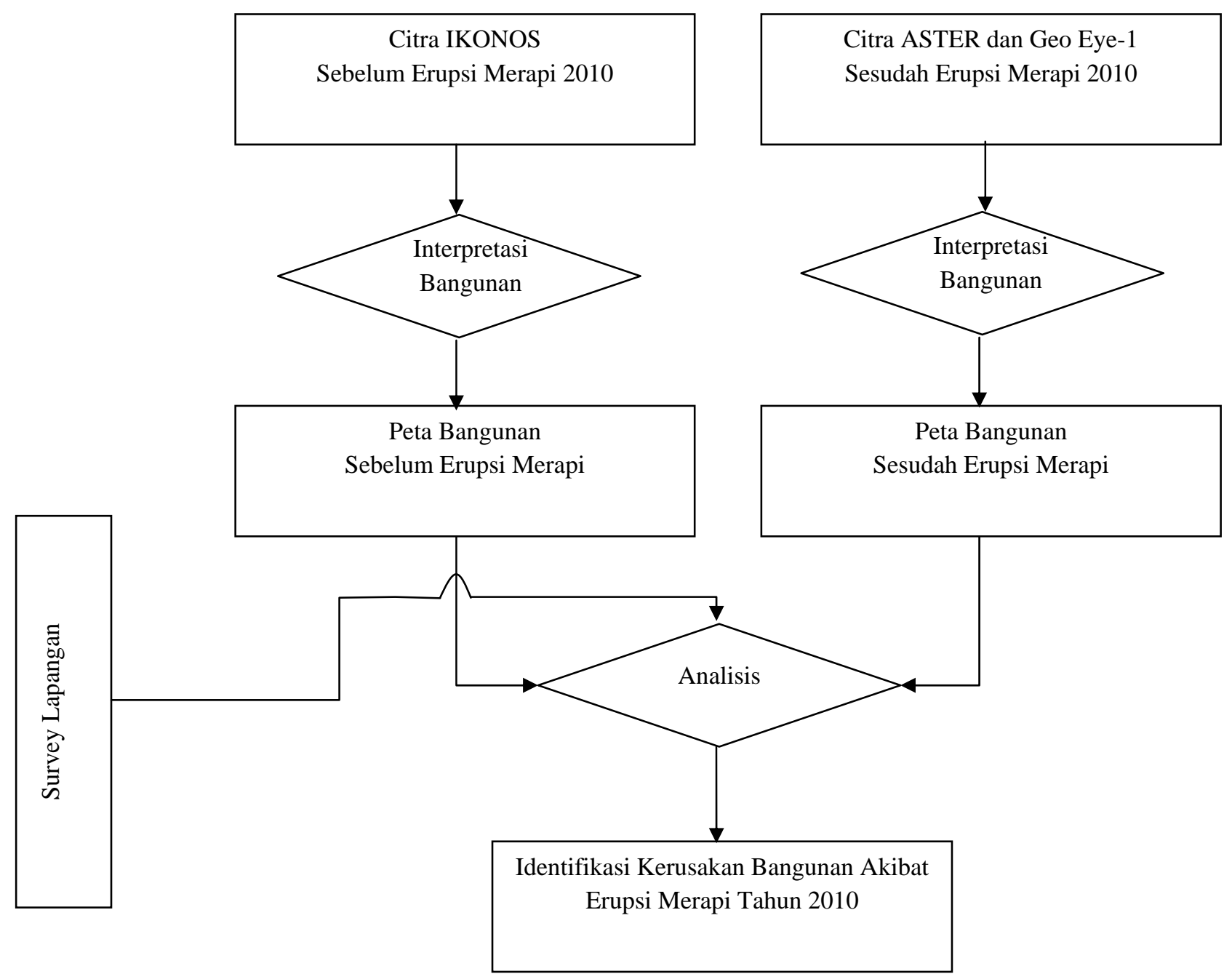

Gambar 1. Diagram Alir Penelitian 


\section{Hasil Penelitian dan Diskusi}

Erupsi Gunungapi Merapi pada tahun 2010 memiliki karakteristik baru, dimana awan panas meluncur mengikuti alur sungai. Akibatnya jarak luncur menjadi lebih jauh dan kerusakan yang ditimbulkan juga lebih parah. Berdasarkan sejarah erupsi Merapi, kondisi tahun 2010 adalah erupsi paling besar dalam kurun waktu 100 tahun terakhir. Berdasarkan kajian dan survei lapangan yang dilakukan terdapat beberapa temuan mengenai dampak awan panas serta zona bahaya awan panas Merapi sesuai dengan karakteristik baru dari Erupsi Tahun 2010, khususnya terhadap kerusakan bangunan. Beberapa hal yang dihasilkan dari penelitian ini diantaranya tingkat kerusakan bangunan akibat erupsi Merapi serta potensi kerusakan bangunan berdasarkan zona rawan bencana Gunungapi Merapi.

\section{Kerusakan Bangunan Akibat Erupsi}

Berdasarkan hasil dari interpretasi Citra ASTER perekaman tanggal 15 November 2010 dapat dilihat bahwa awan panas hasil Erupsi Merapi Tahun 2010 menyusup ke bawah melalui Sungai Gendol dan menerjang beberapa desa di Kecamatan Cangkringan dan sebagian kecil Kecamatan Ngemplak, Kabupaten Sleman yang dilaluinya (Gambar 2). Salah satu dampak primer yang ditimbulkan adalah kerusakan bangunan. Beberapa wilayah yang terkena dampak ini antara lain: Setengah dari wilayah Desa Umbulharjo, Sebagian besar dari wilayah Desa Kepuharjo, Sebagian besar dari wilayah Desa Glagaharjo, Sebagian kecil dari wilayah Desa Wukirsari, dan Sebagian kecil dari wilayah Desa Argomulyo.

Tabel 1 menunjukkan data jumlah bangunan yang rusak aibat awan panas di setiap desa di Kecamatan Cangkringan. Gambar 5 menunjukkan bangunan-bangunan yang terkena terjangan awan panas.

Tabel 1. Data Jumlah Bangunan Rusak Per Desa di Kecamatan Cangkringan

\begin{tabular}{|c|l|c|}
\hline No. & \multicolumn{1}{|c|}{ Nama Desa } & Jumlah Bangunan \\
\hline 1. & Umbulharjo & 301 \\
\hline 2. & Kepuhharjo & 1327 \\
\hline 3. & Glagahharjo & 1021 \\
\hline 4. & Wukirsari & 504 \\
\hline 5. & Argomulyo & 92 \\
\hline \multicolumn{2}{|c|}{ TOTAL } & $\mathbf{3 2 4 5}$ \\
\hline
\end{tabular}

Sumber: Hasil Analisis (2011)

Berdasarkan Tabel 1 diketahui bahwa jumlah bangunan rusak terbanyak berada di Desa Kepuhharjo dan Glagahharjo dan kerusakan paling sedikit dialami bangunan-bangunan di Desa Argomulyo. Bangunan yang mengalami kerusakan terebut meliputi rumah penduduk dan fasilitas lain, seperti 
Masjid 7 buah, Sekolah 5 buah, Puskesmas 1 buah dan Balai Desa 1 Buah. Kerusakan yang diakibatkan hampir semua berkategori berat, kalau pun ada yang masih kelihatan berdiri tapi secara struktur sudah rapuh dan tidak layak huni. Semua bangunan yang rusak harus direkonstruksi yang baru.

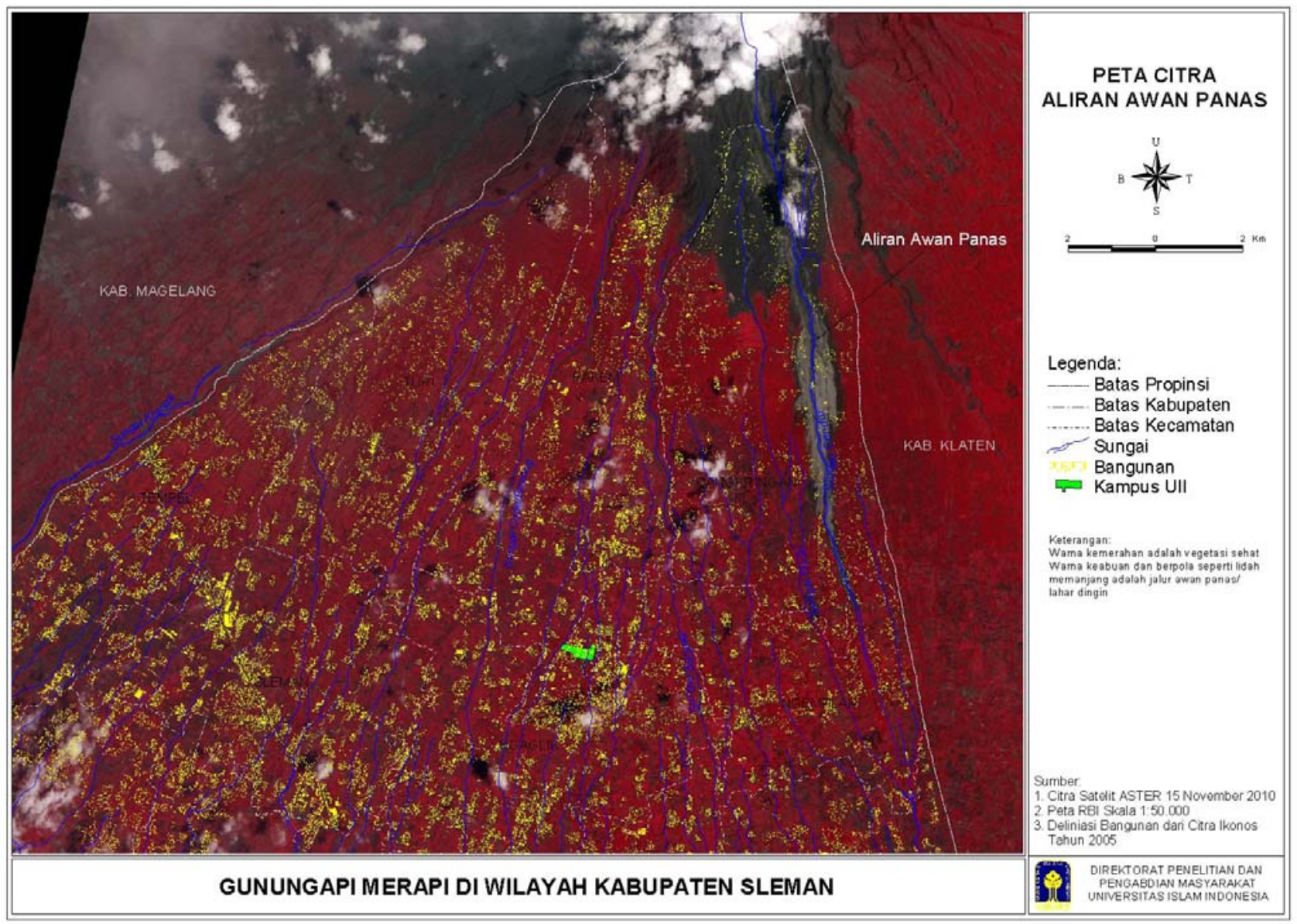

Gambar 2. Peta Aliran Awan Panas Gunungapi Merapi 2010 dan Bangunan yang Diterjang

\section{Potensi Kerusakan Bangunan Berdasarkan Zona Rawan Bencana Gunungapi Merapi PVMBG}

Pusat Vulkanologi dan Mitigasi Bencana Geologi (PVMBG) pada tanggal 31 Januari 2011 telah mengeluarkan Peta Rawan Bencana Merapi yang terbaru. Penambahan luas terjadi dibandingkan peta sebelumnya adalah zona bahaya III di wilayah Kecamatan Cangkringan. Seluruh wilayah yang terkena awan panas pada erupsi Tahun 2010 menjadi zona III. Zona II dan zona I mengikuti radius buffer sekitar $\pm 700 \mathrm{~m}$ dari titik terluar zona III.

Analisis dilakukan dengan melakukan tumpang susun antara Peta bangunan dengan Peta kawasan rawan bencana. Analisis ini menghasilkan jumlah bangunan yang berada di zona rawan bencana, baik rawan bencana III, II dan I. Hasil tumpang susun tersebut sebagaimana tersaji pada Tabel 2 dan Gambar 3. 
Tabel 2. Jumlah Bangunan yang Masuk dalam Kawasan Rawan Bencana

\begin{tabular}{|c|c|c|}
\hline No. & Kawasan Rawan Bencana & Jumlah Bangunan \\
\hline 1. & Zona III & 9330 \\
\hline 2. & Zona II & 16253 \\
\hline 3. & Zona I & 5883 \\
\hline \multicolumn{2}{|c|}{ Total } & $\mathbf{3 1 4 6 6}$ \\
\hline
\end{tabular}

Sumber: Hasil Analisis (2011)

Analisis di atas menggambarkan potensi kerusakan bangunan yang akan terjadi apabila wilayah rawan bencana III masih dihuni kembali setelah erupsi 2010. Berdasarkan Tabel 2 terdapat potensi kerusakan hingga kehancuran bangunan sekitar 9330 buah. Kondisi ini menunjukkan potensi kerusakan yang besar. Oleh karena itu rekomendasi agar wilayah rawan bencana III tidak didirikan bangunan perlu ditindaklanjuti oleh pihak terkait.

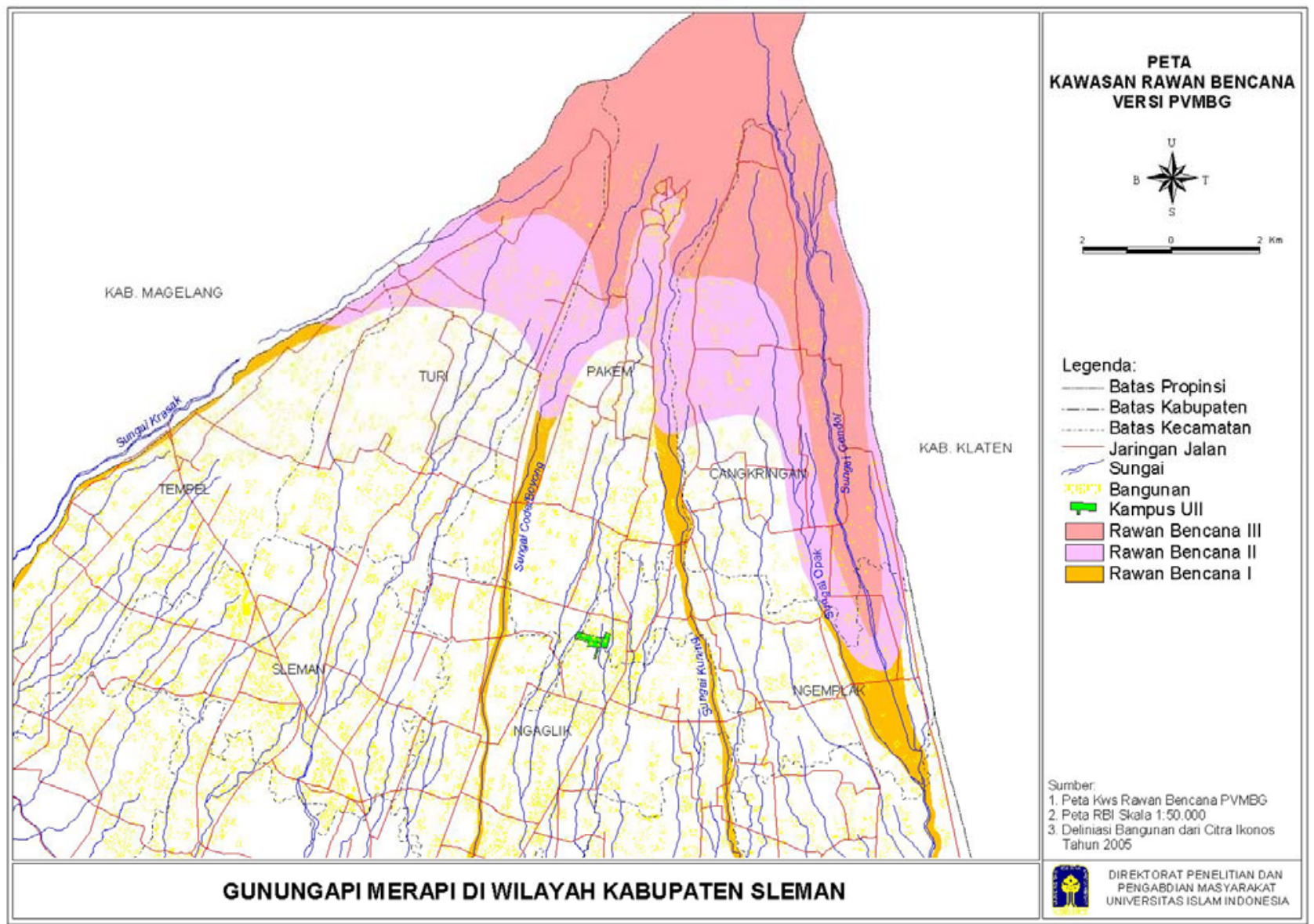

Gambar 3. Peta Kerawanan Bencana Merapi dan Bangunan yang Dilingkupi

\section{Potensi Kerusakan Bangunan Berdasarkan Zona Rawan Bencana Gunungapi Merapi Modifikasi Peneliti}

Berdasarkan peta rawan bencana versi PVMBG dan berdasarkan karakteristik erupsi Merapi Tahun 2010 serta dari kajian kegunungapian maka peneliti mencoba membuat model simulasi luncuran awan panas. Selama ini luncuran awan panas sering berpindah-pindah, pada Tahun 1994 luncuran 
awan panas melalui jalur Sungai Boyong/Code, kemudian pada tahun-tahun sesudahnya meluncur ke arah Sungai Gendol dan terakhir Tahun 2010. Dengan berbekal data tersebut dibuat pengandaian arah luncuran lava (awan panas) tidak hanya mengarah ke Sungai Gendol namun dengan kekuatan yang sama/lebih besar mengarah ke Sungai Code maupun Sungai Kuning. Model yang digunakan adalah mereferensi kejadian luncuran awan panas Tahun 2010 dan juga data kawasan rawan bencana versi PVMBG, dimana terihat bahwa luncuran awan panas sampai menjangkau jarak \pm 16 km dari puncak Gunung Merapi dan mengikti alur sungai. Untuk kiri-kanan sungai yang masih terdampak awan panas berkisar $\pm 700 \mathrm{~m}$ dari as sungai. Pendekatan di atas menghasilkan model seperti terlihat pada Gambar 4.

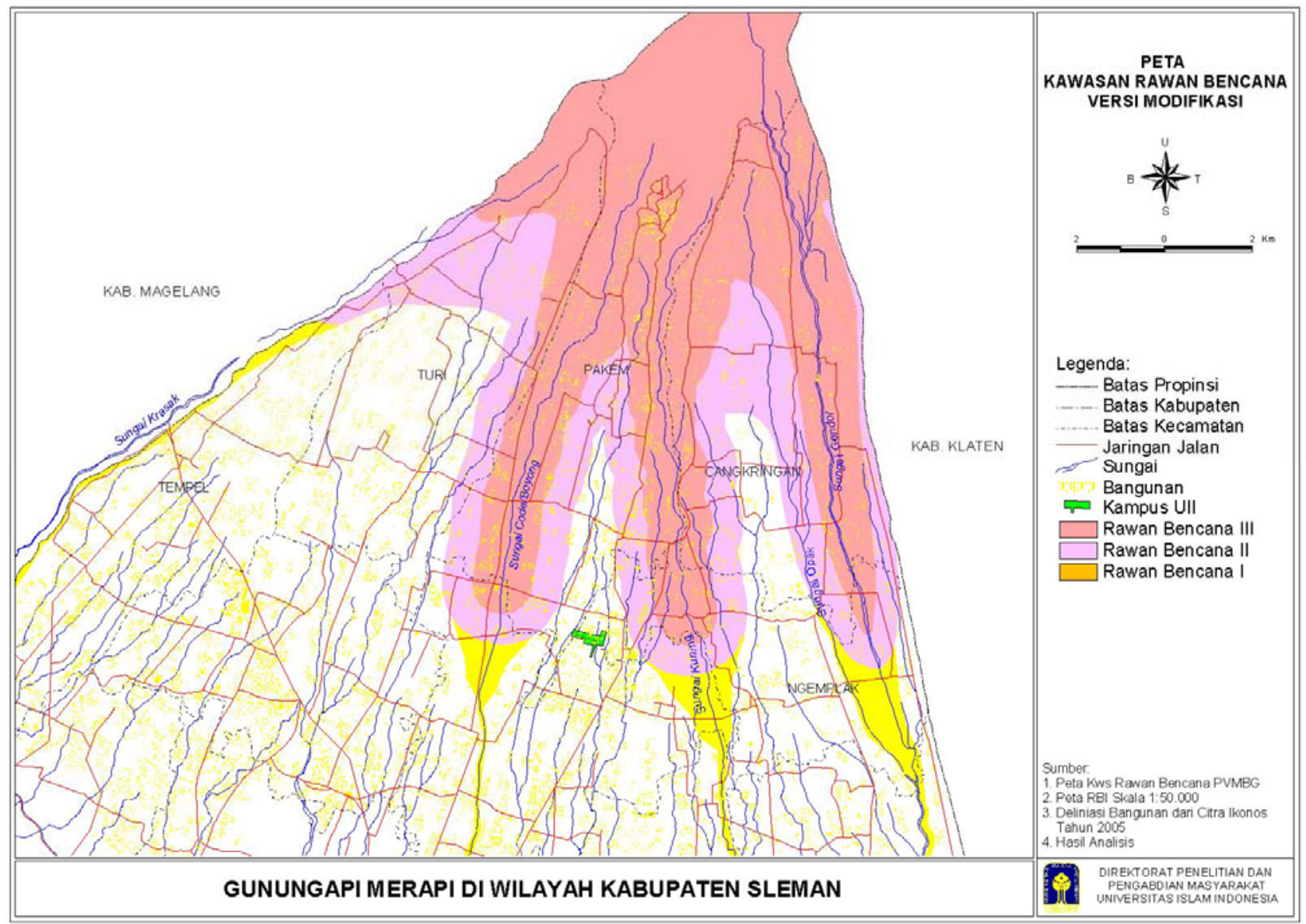

Gambar 4. Peta Rawan Bencana Merapi Modifikasi Peneliti dan Bangunan yang Dilingkupi

Data hasil simulasi kawasan rawan bencana ditumpangsusunkan dengan data bangunan yang ada untuk mengetahui berapa jumlah bangunan yang masuk kawasan rawan bencana. Posisi Kampus UII dalam hal ini berada di zona aman pada peta simulasi yang dibuat secara over estimate ini. Berdasarkan peta rawan bencana versi PVMBG wilayah kampus UII berada di zona aman berjarak sekitar 1,5 - $2 \mathrm{~km}$ dari zona bahaya I, sedangkan berdasarkan peta ini berada di zona aman dengan jarak sekitar 600 - 900 m dari zona bahaya II. 
Tabel 2. Jumlah Bangunan yang Masuk dalam Kawasan Rawan Bencana Versi Modofikasi

\begin{tabular}{|c|c|c|}
\hline No. & Kawasan Rawan Bencana & Jumlah Bangunan \\
\hline 1. & Zona III & 31405 \\
\hline 2. & Zona II & 25384 \\
\hline 3. & Zona I & 6978 \\
\hline & Total & 63767 \\
\hline
\end{tabular}

Sumber: Hasil Analisis (2010)

\section{Rekomendasi Penataan Kawasan Permukiman}

Kerusakan bangunan paling parah berada pada Kawasan Rawan Bencana III Merapi, karena langsung mendapat terjangan awan panas. Dampak erupsi Merapi 2010 yang dahsyat menuntut pemerintah mengambil langkah tegas, bijak, dan adil. Rekomendasi sudah diberikan Pusat Vukanologi dan Mitigasi Bencana Geologi (PVMBG) melalui Peta Kawasan Rawan Bencana Merapi 2011. Secara teknis spasial sudah diberikan batasan kawasan yang direkomendasikan tidak untuk tidak dihuni yaitu Kawasan Rawan Bencana III. Pemerintah daerah, dalam hal ini Kabupaten Sleman menjadi pihak yang diberi kewenangan dan tugas menindaklanjuti rekomendasi tersebut. Penelitian ini turut menguatkan rekomendasi PVMBG dan ditambah dengan rekomendasi teknis operasionalnya.

Solusi menindaklanjuti rekomendasi penataan kawasan rawan bencana III adalah relokasi, baik lokal, regional, atau transmigrasi. Relokasi lokal dapat dilakukan minimal menampati Kawasan Rawan Bencana II. Relokasi regional dapat menempati Kawasan Rawan Bencana I di desa atau kecamatan lain. Pilihan selanjutnya adalah transmigrasi ke luar Pulau Jawa jika memungkinkan. Beberapa hal yang perlu dipertimbangkan pengambil kebijakan relokasi ini antara lain:

a. Pendekatan persuasif dan sistematis berbasis sosial budaya.

b. Relokasi dengan sistem bedol dusun/kampung

c. Penyediaan wilayah tujuan relokasi yang sesuai dengan wilayah asal

d. Sistem tukar lahan

e. Penyediaan fasilitas yang memadai

Selain mekanisme di atas, pemerintah dapat membuka kesempatan dan mendorong masyarakat melakukan transmigrasi. Hal ini tentu harus diimbangi dengan jaminan dan pertimbangan yang cermat.

\section{Rehabilitasi dan Rekonstruksi Rumah dan Fasilitas Lingkungan Permukiman}

Rehabilitasi bangunan perlu mempertimbangkan kearifan lokal serta optimalisasi secara fungsional. Kepadatan bangunan perlu memperhatikan Koefisien Dasar Bangunan yang renggang dan masih 
mengakomodasi pekarangan serta penghijauan. Pemerintah perlu segera memprioritaskan rehabilitasi ini karena menjadi beban berat bagi masyarakat. Fasilitas permukiman juga perlu segera dilakukan rehabilitasi hingga pembangunan baru sesuai kebutuhan. Fasilitas tersebut antara lain temat ibadah, masjid, kantor, sekolah, jalan, dan jaringan air bersih. Fasilitas yang perlu dirancang baru adalah jalur evakuasi, tempat pengungsian, dan pengaman banjir lahar dingin. Banyak pihak yang memberikan bantuan, untuk itu pemerintah perlu menggkoordinasikan dan mengarahkan agar kualitasnya memadai.

Pembangunan total dilakukan untuk Kawasan Rawan Bencana III. Berdasarkan arahan yang direkomendasikan sebelumnya, kawasan itu harus kosong dari hunian dan diarahkan untuk relokasi. Dengan demikian rekonstruksi juga diarahkan menempati wilayah relokasi baru. Setelah proses relokasi berhasil, maka yang perlu diperhatikan adalah pembangunan di daerah relokasi. Pembangunan hendaknya masih mengikuti kearifan bangunan lokal serta memperhatikan penyediaan fasilitas yang memadai dan fungsional. Pembangunan ini menjadi titik yang penting dan kesempatan yang baik untuk memulai penataan sekaligus pembangunan permukiman yang ramah sosial dan lingkungan. Penelitian ini akan secara khusus memberikan arahan untuk pembangunan fasilitas lingkungan permukiman. Fasilitas lingkungan permukiman yang mesti diperhatikan antara lain fasilitas air bersih, fasilitas air limbah dan MCK, fasilitas pengelolaan sampah, fasilitas ruang publik, serta fasilitas jalan dan drainase.

\section{Kesimpulan}

1. Daerah yang mengalami kerusakan bangunan berat akibat erupsi Gunungapi Merapi tahun 2010 antara lain setengah dari wilayah Desa Umbulharjo, sebagian besar dari wilayah Desa Kepuhharjo, sebagian besar dari wilayah Desa Glagahharjo, sebagian kecil dari wilayah Desa Wukirsari, dan sebagian kecil dari wilayah Desa Argomulyo, semuanya Kecamatan Cangkringan .

2. Jumlah bangunan rusak berdasarkan hasil analisis adalah 3245 buah, dengan rincian 301 buah di Desa Umbulharjo, 1327 buah di Desa Kepuhharjo, 1021 buah di Desa Glagahharjo, 504 buah di Desa Wukirsari, dan 92 buah di Desa Argomulyo.

3. Fasilitas permukiman yang rusak antara lain masjid 7 buah, sekolah 5 buah, Puskesmas 1 buah dan balai desa 1 buah.

4. Penataan permukiman Kawasan Rawan Bencana III Merapi harus dengan relokasi, baik lokal, regional, maupun transmigrasi. 
5. Beberapa hal yang perlu dipertimbangkan dalam kebijakan relokasi antara lain:

a. Pendekatan persuasif dan sistematis berbasis sosial budaya.

b. Relokasi dengan sistem bedol dusun/kampung

c. Penyediaan wilayah tujuan relokasi yang sesuai dengan wilayah asal

d. Sistem tukar lahan

e. Penyediaan fasilitas yang memadai.

6. Fasilitas lingkungan permukiman perlu disediakan dalam program rehabilitasi dan rekonstruksi antara lain akses air bersih, pengelolaan limbah, pengelolaan sampah terpadu, akses jalan dan drainase, fasilitas tanggap darurat bencana, serta ruang publik.

\section{Ucapan Terima Kasih}

Penulis secara khusus menyampaikan terima kasih kepada: Direktorat Penelitian dan Pengabdian pada Masyarakat (DPPM) UII, Pemerintah Kabupaten Sleman, dan Tim Surveyor.

\section{Daftar Pustaka}

BNPB. (2010). Laporan Harian Tanggap Darurat Gunung Merapi Tanggal: 6 November 2010 pukul 24.00 WIB, Jakarta.

Lupiyanto, Ribut. (2005). Daya Dukung Lingkungan Kawasan Rawan Bencana III Gunungapi Merapi, Skripsi, Yogyakarta: Fakultas Geografi Universitas Gadjah Mada.

PSBA/BAKOSURTANAL. (2005). Laporan Akhir Pengkajian Model Pemetaan Risiko Bencana Alam. Kerjasama Pusat Pelayanan Jasa dan Informasi BAKOSURTANAL - Pusat Studi Bencana Alam Universitas Gadjah Mada, Yogyakarta.

Rengers, N., Westen, V.K. (1994). Application of Satellite Remote Sensing for Natural Disaster Reduction in Developing Countries, World Conferences on Natural Disaster Reduction, Yokohama, pp.39-44.

Sutanto. (1995). Penginderaan Jauh Dasar, Yogyakarta: GMU Press. 